\title{
Combined Effect on Antioxidant Properties of Gymnema Sylvestre and Combretum Micranthum Leaf Extracts and the Relationship to Hypoglycemia
}

\author{
Ibrahim A., \\ Department of Biochemistry, Bayero University, Kano \\ Department of Biochemistry, Ahmadu Bello University, Zaria \\ Onyike E., \\ Nok A. J. \\ Umar I. A. \\ Department of Biochemistry, Ahmadu Bello University, Zaria
}

Doi: 10.19044/esj.2017.v13n36p266 URL:http://dx.doi.org/10.19044/esj.2017.v13n36p266

\begin{abstract}
Gymnema sylvestre R.Br. ("periploca of the woods" in English; "Kafi suga" in Hausa) (Asclepiadaceae) and Combretum micranthum, Fam. (Géézà in Hausa) (Combretaceae)) are used in combination for the management of diabetes mellitus (DM) in the North-Eastern part of Nigeria with little or no scientific basis. It is thus the aim of this research to validate the anti-diabetic activities of $G$. sylvestre (GS) and $C$. micranthum (CM) leaf extracts, individually and in combined form (GSCM) as well as look at the relationship between antioxidant capacity and anti-hyperglycemic potential of these plants. The study assayed for anti-diabetic potential by following fasting blood glucose (FBG). Levels of liver catalase (CAT), malondialdehyde (MDA), superoxide dismutase (SOD), reaction oxygen species (ROS), reduced glutathione (GSH), oxidized glutathione (GSSG) and glutathione peroxidase (GSH-Px), and radical scavenging activities of the plants were assayed for spectrophotometrically. GS and CM revealed good ferric reducing antioxidant power (FRAP) and radical scavenging activities against ABTS, DPPH and Nitric Oxide with $C$. micranthum being significantly better - both plants also showed good total flavonoids and total phenolic contents. The anti-hyperglycemic activities may be associated with flavonoids and phenolic compounds which act via radical scavenging/antioxidant properties of the plants' extracts. In conclusion, $G$. sylvestre and $C$. micranthum aqueous leaf extracts showed significant $(\mathrm{P}<$ $0.05)$ hypoglycaemic activities both separately and in a 1:1 combination
\end{abstract}


which has strong correlation with both in vitro and in vivo antioxidant activities of the plants' extracts.

Keywords: Herbal combination, antioxidants, diabetes mellitus

\section{Introduction}

Antioxidants protect cells against the damaging effects of reactive oxygen species otherwise called, free radicals such as singlet oxygen, super oxide, peroxyl radicals, hydroxyl radicals and peroxynitrite which results in oxidative stress leading to cellular damage. Natural antioxidants play a key role in health maintenance and prevention of the chronic and degenerative diseases, such as atherosclerosis, cardiac and cerebral ischemia, carcinogenesis, neurodegenerative disorders, diabetic pregnancy, rheumatic disorder, DNA damage and ageing (Touré et. al., 2011; Kang et.al., 2012; Prathapan et. al., 2012; Adedara et. al., 2014; Mistry and Mona, 2015). Antioxidants exert their activity by scavenging the 'free-oxygen radicals' thereby giving rise to a fairly 'stable radical'. The free radicals are metastable chemical species, which tend to trap electrons from the molecules in the immediate surroundings. These radicals if not scavenged effectively in time, may damage crucial biomolecules like lipids, proteins including those present in all membranes, mitochondria and the DNA, resulting in abnormalities leading to disease conditions (Timbrell, 1996). Thus, free radicals are involved in a number of diseases including: tumour inflammation, haemorrhagic shock, atherosclerosis, diabetes, infertility, gastrointestinal ulcerogenesis, asthma, rheumatoid arthritis, cardiovascular disorders, cystic fibrosis, neurodegenerative diseases (e.g. Parkinsonism, Alzheimer's diseases), AIDS and even early senescence. The human body produces insufficient amount of antioxidants which are essential for preventing oxidative stress. Free radicals generated in the body can be removed by the body's own natural antioxidant defences such as glutathione or catalases. Therefore, these natural antioxidants had to be compensated by making use of natural exogenous ones, such as vitamin $\mathrm{C}$, vitamin $\mathrm{E}$, flavones, $\beta$-carotene and some natural products in plants (Doughari, 2012).

Plants contain a wide variety of free radicals scavenging molecules including phenols, flavonoids, vitamins, terpenoids that are rich in antioxidant activity. Combretum micranthum Fam. belong to the family of Combretaceae. It is a widely known ethnomedicinal plant used in West Africa for treating several conditions and in North-western Nigeria; it is used for managing diabetes mellitus. Ethanol extract of Combretum micranthum leaves is reported to be rich in polyphenols (tannins, flavonoids and other components) constituents known to possess various beneficial pharmacological properties such as antioxidant, anti-mutagenic, anti- 
carcinogenic, hypolipidemic and cardioproprotective activities (Chika and Bello, 2010). The antioxidant, antimicrobial, anti-diarrhoeal as well as antiinflammatory properties of the plant have also been documented (Touré et. al., 2011; Abdullahi et. al., 2014). Polyphenols in C. micranthum were also found to be responsible for its hypoglycemic and anti-diabetic property (Upendra et. al., 2010). G. sylvestre R.Br. is a perennial, woody climber belonging to family Asclepiadaceae or the "milk weed" family. The genus consists of 40 species, some of which like $G$. sylvestre, G. montanum, $G$. yunnanense, and $G$. inodorum have medicinal properties. The plant is found in tropical and subtropical regions; it is well distributed in parts of central and southern India and in the southern part of China, tropical Africa, Malaysia, and Sri Lanka. G. sylvestre is slow growing herb, found ideally in tropical and subtropical humid climate and common in hills of evergreen forests (Tiwari et. al., 2014). Leaves of $G$. sylvestre have acidic glycosides and anthraquinones and their derivatives. The major secondary metabolites in Gymnema includes a group of nine closely related acidic glycosides, the main are gymnemic acid A-D and found in all parts of the plant; gymnemic acid has been found to interact with glyceraldehyde-3-phosphate dehydrogenase, a key enzyme in glycolysis pathway and the findings also indicated that the gymnemic acids play an integral role in the antihyperglycemic activity of GS (Tiwari et. al., 2014).

\section{Materials and methods \\ Materials \\ Plant material collection and identification}

Fresh samples of the plants Gymnema sylvestre (GS) and Combretum micranthum (CM) were obtained from Shira Local Government Area $\left(\mathrm{N} 11^{\mathrm{O}}\right.$ 27 ' 29" and E $10^{\circ} 2$ ' 48') of Bauchi State in Nigeria. The plants were identified at the herbarium unit of Department of Biological Sciences, Bayero University, Kano (B.U.K.) and voucher specimens, with number BUKHAN 0349 (for Gymnema sylvestre) and BUKHAN 0272 (for Combretum micranthum) were then deposited in the same herbarium.

\section{Animals}

Adult male wistar rats $(150$ - 200 g body weight $)$ were purchased from the department of Pharmacology and Therapeutics of Ahmadu Bello University, Zaria. They were kept in standard metal animal cages at room temperature in the animal house of Biological Sciences Department, B.U.K., were allowed free access to food and water and allowed to acclimatize for a week prior to use. The protocol of the study was according to international guidelines i.e. the Organization for Economic Cooperation and Development (OECD) Test Guidelines (TG407) (OECD, 2006). 


\section{Chemicals, Reagents and Equipment}

All the chemicals and reagents used for this work were of analytical grade and purchased from reputable chemical manufacturers, e.g. SIGMAALDRICH-FLUKA. The laboratory equipment were also of standard quality.

\section{Methods}

\section{Preparation of plant material (extracts)}

The leaves of the plants Gymnema sylvestre (GS) and Combretum micranthum $(\mathrm{CM})$ used for the study were plucked from the stem, washed and then dried under shade. The dried samples were then ground into powder in a laboratory mortar using a pestle. The powdered samples were then kept in a closed plastic container for use in the experiment.

Aqueous Extraction: Two hundred grams of the air-dried samples of each plant were cold extracted with $2000 \mathrm{ml}$ of distilled water $-3 \mathrm{X}$.

\section{DPPH Radical Scavenging Activity}

2,2- diphenyl-1-picryhydrazyl (DPPH) radical scavenging activity was measured using the method as described in Naskar et al, (2010). Three ( $3) \mathrm{ml}$ of reaction mixture containing $0.2 \mathrm{ml}$ of DPPH $(100 \mu \mathrm{M}$ in methanol) and $2.8 \mathrm{ml}$ of test solution, at various concentrations $(5,10,20,40,80,160$ $320 \mu \mathrm{g} / \mathrm{ml}$ ) of the extract/fractions was incubated at $37^{\circ} \mathrm{C}$ for $30 \mathrm{~min}$, absorbance of the resulting solution was measured at $517 \mathrm{~nm}$ using spectrophotometer. The percentage inhibition of DPPH radical was calculated by comparing the results of the test with those of the control (not treated with extract) using the following equation:

Percentage inhibition $=(1-$ absorbance of test/absorbance of control $)$ $\times 100$

\section{Nitric Oxide Radical Scavenging Activity}

One (1) $\mathrm{ml}$ of $10 \mathrm{mM}$ sodium nitroprusside was mixed with $1 \mathrm{ml}$ of test solution of different concentrations $(80,160,320,500,800,1000 \mu \mathrm{g} / \mathrm{ml})$ in phosphate buffer ( $\mathrm{pH} \mathrm{7.4)}$ ) and the mixture incubated at $25^{\circ} \mathrm{C}$ for $150 \mathrm{~min}$. From the incubated mixture, $1 \mathrm{ml}$ was taken out, $1 \mathrm{ml}$ of Griess' reagent $(1 \%$ sulphanilamide, $2 \%$ o-phosphoric acid $0.1 \%$ naphthyl ethylene diamine dihydrochloride) added to it. Absorbance of the chromophore formed by the diazotization of nitrite with sulphanilamide subsequent coupling with naphthyl ethylene diamine dihydrochloride was read at $546 \mathrm{~nm}$ and percentage inhibition calculated by comparing the results of the test with those of the control using Eq. (1) above Naskar et. al., (2010). 


\section{Ferric Reducing Antioxidant Power (FRAP)}

Reducing power of the test samples was determined on the basis of the ability of their antioxidant principles to form coloured complex with potassium ferricyanide, $\mathrm{TCA}, \mathrm{FeCl}_{3}$. It was measured by the method reported by Naskar et. al., (2010). A $1 \mathrm{ml}$ of different concentrations (25, 50, 100, $200,400 \mu \mathrm{g} / \mathrm{ml}$ ) of the extract fractions was mixed with potassium ferricyanide $(2.5 \mathrm{ml}, 1 \%), 2.5 \mathrm{ml}$ of phosphate buffer $(\mathrm{pH} 6.6)$. The mixture was incubated at $50^{\circ} \mathrm{C}$ for $20 \mathrm{~min} .2 .5 \mathrm{ml} \mathrm{TCA}(10 \%)$ was added to it and centrifuged at $3000 \mathrm{rpm}$ for $10 \mathrm{~min}$. $2.5 \mathrm{ml}$ of supernatant was taken out and to this $2.5 \mathrm{ml}$ water, $0.5 \mathrm{ml} \mathrm{FeCl}_{3}(0.1 \%)$ was added and absorbance measured at $700 \mathrm{~nm}$. Higher absorbance of the reaction mixture indicated higher reducing power.

\section{ABTS Scavenging Effects}

The antioxidant effect of the leaf extracts was also studied using ABTS (2,2'-azino-bis-3-ethyl benzthiazoline-6-sulphonic acid) radical cation decolourisation assay according to the method of Shirwaikar et. al., (2006). Briefly, ABTS radical cations $\left(\mathrm{ABTS}^{+}\right)$were produced by reacting ABTS solution $(7 \mathrm{mM})$ with $2.45 \mathrm{mM}$ ammonium persulphate. The mixture was allowed to stand in the dark at room temperature for 12-16 hours before use. Aliquots $(0.5 \mathrm{ml})$ of the extracts were added to $0.3 \mathrm{ml}$ of ABTS solution and the final volume was made up to $1 \mathrm{ml}$ with ethanol. The absorbance was read at $745 \mathrm{~nm}$ in a spectrophotometer and the per cent inhibition was calculated using the formula below.

SCAVENGING ACTIVITY $(\%)=$

$\frac{[(A B S O R B A N C E 745 \mathrm{~nm} \text { of control-ABSORBANCE } 745 \mathrm{~nm} \text { of sample })]}{[(\text { ABSORBANCE } 745 \mathrm{~nm} \text { of control })]} \times 100$

\section{Total Antioxidant Capacity}

Total antioxidant capacity (TAC) of the plant samples was determined using an automated measurement method, developed by Erel (2005) with modification - ascorbic acid was used in place of trolox. In this method, the characteristic colour of ABTS $^{*+}$ is bleached by antioxidants present in the sample. This reaction can be monitored spectrophotometrically and the bleaching rate is inversely related to the TAC of the sample. The reaction rate is calibrated with ascorbic acid, as a traditional standard, and the assay results are expressed in ascorbic acid equivalent, $\mu \mathrm{g} / \mathrm{g}$ dry weight of plant sample.

\section{Catalase activity (CAT)}

This is based on coupled oxidation, according to the method of Clairborne (1995); 50 $\mu 1$ of sample was mixed with the reagents ammonium ferrous sulphate $(2.5 \mathrm{ml})$, sorbitol $(250 \mu \mathrm{l})$, xylenol orange $(100 \mu \mathrm{l}), \mathrm{H}_{2} \mathrm{O}_{2}$ 
$(25 \mu 1)$, and incubated at room temperature for 30 minutes. The absorbance was read at $560 \mathrm{~nm}$ spectrophotometrically. The concentration of hydrogen peroxide generated was extrapolated from the standard curve.

\section{Total Plasma Peroxide (TPP)/Reactive Oxygen Species (ROS)}

Total Plasma Peroxide (TPP) levels were determined using the ferrous oxidation (FOX2) method (Miyazawa, 1989) with minor modifications (Yeni et al, 2005).

$200 \mu \mathrm{L}$ of plasma $+1800 \mu \mathrm{L}$ FOX-2 reagent was incubated at room temperature for 30 minutes and centrifuged at 3000rpm for 10 minutes. The absorbance of the supernatant was measured at 560nm. Total plasma peroxide content of the homogenate samples were determined using a solution of $\mathrm{H}_{2} \mathrm{O}_{2}$ (hydrogen peroxide) as standard $\left(100 \mu \mathrm{M} \mathrm{H}_{2} \mathrm{O}_{2}\right)$.

\section{Reduced (GSH) \& Oxidized (GSSG) Glutathione Levels}

The method of Beutler et .al. (1963) was followed in estimating the level of reduced glutathione (GSH). An aliquot of the sample was deproteinised by the addition of an equal volume of $4 \%$ sulphur-salicylic acid. This was centrifuged at $10,000 \mathrm{~g}$ for 5 minutes at $4^{\circ} \mathrm{C}$. Thereafter, $0.5 \mathrm{ml}$ of the supernatant was added to $4.5 \mathrm{ml}$ of Ellman's reagent. A blank was prepared with $0.5 \mathrm{ml}$ of the diluted precipitating agent and $4.5 \mathrm{ml}$ of Ellman's reagent. Reduced glutathione, GSH, is proportional to the absorbance at $412 \mathrm{~nm}$. For GSSG determination, 2-vinylpyridine was used to derivatize GSH (Puertas et. al., 2012).

\section{Superoxide Dismutase (SOD) Activity}

The level of SOD activity was determined by the method of Misra and Fridovich (1972). A $1 \mathrm{ml}$ sample was diluted in $9 \mathrm{ml}$ of distilled water to make a 1 in 10 dilution. An aliquot of $0.2 \mathrm{ml}$ of the diluted sample was added to $2.5 \mathrm{ml}$ of $0.05 \mathrm{M}$ carbonate buffer $(\mathrm{pH} 10.2)$ to equilibrate in the spectrophotometer and the reaction started by the addition of $0.3 \mathrm{ml}$ of freshly prepared $0.3 \mathrm{mM}$ adrenaline to the mixture which was quickly mixed by inversion. The reference cuvette contained $2.5 \mathrm{ml}$ buffer, $0.3 \mathrm{ml}$ of substrate (adrenaline) and $0.2 \mathrm{ml}$ of water. The increase in absorbance at $480 \mathrm{~nm}$ was monitored every 30 seconds for 150 seconds. 1 unit of SOD activity was given as the amount of SOD necessary to cause $50 \%$ inhibition of the oxidation of adrenaline.

\section{Glutathione Peroxidase Assay}

This is based on coupled oxidation according to Rotruck et.al., (1973) method. The assay protocol is as tabulated below. 
Assay protocol:

\begin{tabular}{|c|c|}
\hline Phosphate buffer & $500 \mu \mathrm{l}$ \\
\hline $\mathrm{NaN3}$ & $100 \mu \mathrm{l}$ \\
\hline $\mathrm{GSH}$ & $200 \mu \mathrm{l}$ \\
\hline $\mathrm{H}_{2} \mathrm{O}_{2}$ & $100 \mu \mathrm{l}$ \\
\hline Sample & $500 \mu \mathrm{l}$ \\
\hline Distilled water & $600 \mu \mathrm{l}$ \\
\hline
\end{tabular}

The whole reaction mixture was incubated at $37^{\circ} \mathrm{C}$ for 3 minutes after which $0.5 \mathrm{ml}$ of TCA was added and thereafter centrifuged at $3000 \mathrm{rpm}$ for 5 minutes. To $1 \mathrm{ml}$ of each of the supernatants, $2 \mathrm{ml}$ of $\mathrm{K}_{2} \mathrm{HPO}_{4}$ and $1 \mathrm{ml}$ of DTNB was added and the absorbance was read at $412 \mathrm{~nm}$ against a blank. Glutathione peroxidase activity was extrapolated from the standard curve.

\section{Estimation of Malondialdehyde (MDA) (Niehaus and Samuelson, 1968)}

Lipid peroxidation was determined by measuring the thiobarbituric acid reactive substances (TBARS) produced during lipid peroxidation. A $200 \mu \mathrm{l}$ of the sample was deproteinised with $0.5 \mathrm{ml}$ of Trichloroacetic acid (TCA) and centrifuged at 3000rpm for 10mins. One (1) $\mathrm{ml}$ of $0.75 \%$ TBA was added to $0.1 \mathrm{ml}$ of supernatant and boiled in water bath for 20 minutes at $100^{\circ} \mathrm{C}$ and then cooled on iced water. The absorbance was read spectrophotometrically at $535 \mathrm{~nm}$.

The concentration of MDA was calculated by the absorbance coefficient of MDA-TBA complex at $1.56 \times 10^{5} \mathrm{~cm}^{-1} \mathrm{M}^{-1}$, and expressed in $\mu$ mol TBARS $\mathrm{mg}^{-1}$ tissue protein.

\section{Induction of Diabetes}

Diabetes mellitus (IDDM) was induced by a single intraperitoneal injection of streptozotocin $(60 \mathrm{mg} / \mathrm{kg})$ in sterile citrate buffer $(\mathrm{pH} 4.5 ; 0.1 \mathrm{M})$ to rats (Chatzigeorgiou et. al., 2009) after an overnight fast.

Experimental design (Antidiabetic Studies)

The aqueous plant extracts were used for this phase of the study. A total of 36 rats were used for this phase of the experiment and they were divided into six groups with six rats per group as outlined below:

Group 1, normal untreated rats (given only water; $0.5 \mathrm{ml} / 100 \mathrm{~g}$ body weight);

Group 2, diabetic control rats (given only water; $0.5 \mathrm{ml} / 100 \mathrm{~g}$ body weight);

Group 3, diabetic rats treated with GS alone $(600 \mathrm{mg} / \mathrm{kg}$ body weight); weight);

Group 4, diabetic rats treated with $\mathrm{CM}$ alone $(600 \mathrm{mg} / \mathrm{kg}$ body 
weight);

Group 5, diabetic rats treated with GSCM (1:1) $(600 \mathrm{mg} / \mathrm{kg}$ body

Group 6, diabetic rats treated with glibenclamide $(6 \mathrm{mg} / \mathrm{kg}$ body weight) (Ramkumar et. al., 2011).

\section{Results}

\section{In-vitro Antioxidant (Radical Scavenging) Activity}

The aqueous extracts of GS and CM leaves showed good total flavonoids and total phenolic contents with GS being significantly $(\mathrm{P}<0.05)$ better than CM. Ferric reducing antioxidant power (FRAP) of the two plants also revealed GS to be better than the CM aqueous leaf extract (Figure 1). Also, the aqueous leaf extract of GS displayed significantly better scavenging activities against ABTS, DPPH and Nitric Oxide when compared to the $\mathrm{CM}$ extract, with an $\mathrm{IC}_{50}$ of between 57.26 and $9.34 \mu \mathrm{g} / \mathrm{ml}$ (Figure 2).

\section{In vivo Antioxidant Activity}

Catalase, GSH, GSSG and GSH - Px of the liver homogenate did not show any significant changes - there is a general insignificant increases. However, MDA levels in the liver increased significantly $(\mathrm{P}<0.05)$ in the group administered $600 \mathrm{mg} / \mathrm{kg}$ b.w. GS (Table 1) with the group administered 1:1 GSCM showing the least increase in MDA levels.

\section{Antidiabetic Studies}

Diabetic control group showed increase in FBG which was reduced significantly when treated with GS, CM and GSCM (1:1) after two weeks (Table 2). Percentage decrease in FBG correlates significantly with ABTS, DPPH and nitric oxide (Table 3) on one hand, and also with MDA on the other (Table 4). Moreover, total flavonoid / total phenolic contents showed strong correlations with the levels of the radicals ABTS, DPPH and nitric oxide (Table 3). Moreso, ROS and MDA showed significantly strong correlation (Table 4). 


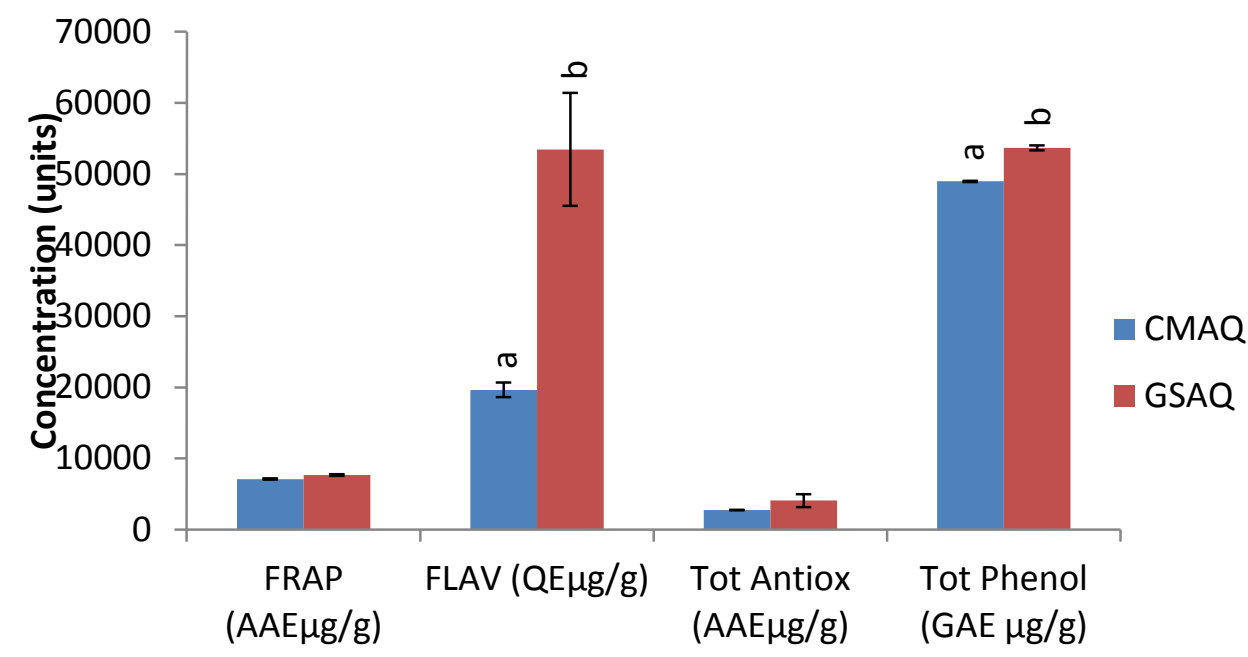

Figure 1: Ferric reducing antioxidant power, total flavonoids \& total phenolics contents of aqueous leaf extracts of $G$. sylvestre and $C$. micranthum

Values expressed as Mean \pm SEM of triplicate measurements, with those bearing different superscripts on the same cluster significantly different $(\mathrm{P}<0.05) . \mathrm{AAE}=$ ascorbic acid equivalent; $\mathrm{QE}=$ quercetin equivalent; $\mathrm{GAE}$ $=$ gallic acid equivalent.

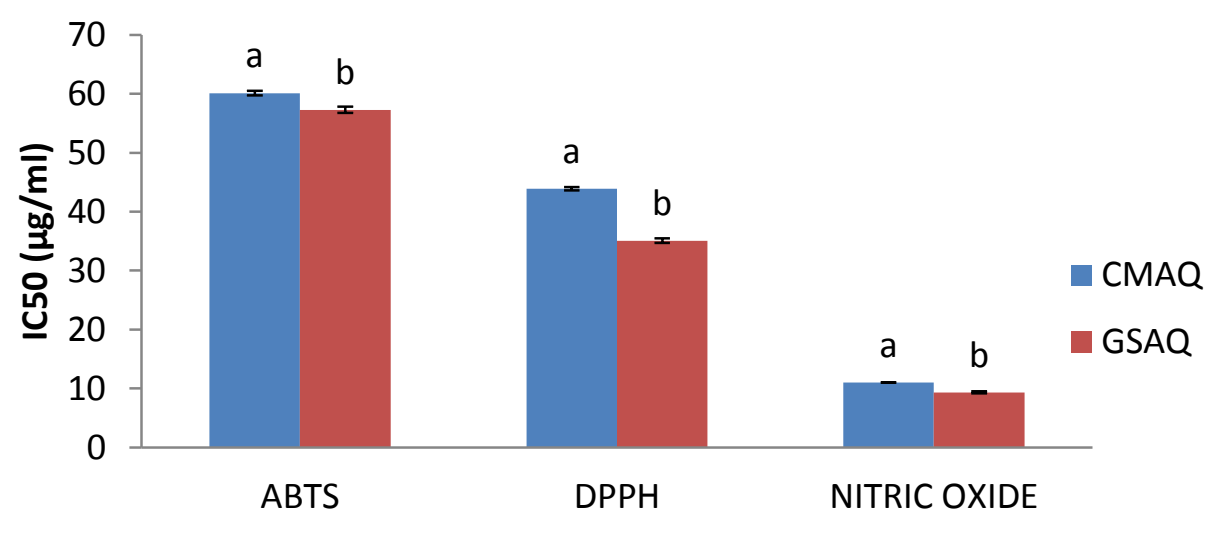

Figure 2: Radical Scavenging Activities of Aqueous Leaf Extracts of G.sylvestre \& $C$. micranthum

Values expressed as Mean \pm SEM of triplicate measurements, with those bearing different superscripts on the same cluster significantly different $(\mathrm{P}<0.05)$. 
Table 1: Some Liver Antioxidant Indices of Rats Administered G. Sylvestre, C. micranthum and 1:1 Combination of Their Aqueous Leaf Extracts

\begin{tabular}{|c|c|c|c|c|c|c|c|}
\hline \multirow[b]{2}{*}{ Group } & \multicolumn{7}{|c|}{ Mean Antioxidant Parameters } \\
\hline & $\begin{array}{c}\text { CAT } \\
(\mu \mathrm{mol} / \mathrm{mg} \\
\text { protein })\end{array}$ & $\begin{array}{c}\mathrm{TPP} / \mathrm{ROS} \\
(\mu \mathrm{mol} / \mathrm{min} / \mathrm{mg} \\
\text { protein })\end{array}$ & $\begin{array}{c}\text { GSH } \\
\text { (U/mg } \\
\text { protein) }\end{array}$ & $\begin{array}{c}\text { GSSG } \\
\text { (U/mg } \\
\text { protein) }\end{array}$ & $\begin{array}{c}\text { SOD } \\
\text { (U/mg } \\
\text { protein) }\end{array}$ & $\begin{array}{c}\text { GSH-PX } \\
\text { (U/mg } \\
\text { protein) }\end{array}$ & $\begin{array}{c}\mathrm{MDA}(\mu \mathrm{molTBARS} / \mathrm{mg} \\
\text { protein })\end{array}$ \\
\hline $\begin{array}{l}\text { normal } \\
\text { control }\end{array}$ & $10.00 \pm 2.19$ & $14.87 \pm 3.37$ & $6.37 \pm 1.58$ & $6.17 \pm 0.41$ & $4.67 \pm 0.35$ & $5.87 \pm 0.74$ & $47.23 \pm 3.69^{\mathrm{a}}$ \\
\hline $\begin{array}{c}\text { normal } \\
600 \\
\text { GS }\end{array}$ & $9.83 \pm 1.12$ & $23.10 \pm 4.38$ & $5.53 \pm 0.78$ & $5.77 \pm 1.12$ & $5.67 \pm 0.63$ & $7.37 \pm 0.52$ & $87.49 \pm 6.56^{\mathrm{b}}$ \\
\hline $\begin{array}{c}\text { normal } \\
600 \\
\mathrm{CM}\end{array}$ & $8.03 \pm 1.35$ & $19.33 \pm 1.10$ & $5.47 \pm 0.69$ & $5.07 \pm 0.87$ & $5.07 \pm 1.2$ & $6.63 \pm 0.69$ & $78.17 \pm 11.82$ \\
\hline $\begin{array}{c}\text { normal } \\
600 \\
\text { GSCM }\end{array}$ & $8.00 \pm 1.70$ & $19.90 \pm 2.60$ & $6.73 \pm 0.90$ & $7.1 \pm 1.37$ & $5.43 \pm 0.52$ & $4.97 \pm 0.46$ & $61.67 \pm 15.07$ \\
\hline
\end{tabular}

Values are mean \pm standard error of mean with those bearing different superscripts within the same column being significantly $(\mathrm{P}<0.05)$ different. $\mathrm{N}=6$.

Table 2: Percentage (\%) Changes in Mean Fasting Blood Glucose of Streptozotocin-

Diabetic Rats Administered Different Doses of G.sylvestre, C.micranthum and 1:1 Combination of Their Aqueous Leaf Extracts for 14 Days

\begin{tabular}{c|c}
\hline Group & Percentage (\%) change in Fasting Blood Glucose (FBG) \\
\hline Normal control & $-7.39 \pm 4.00$ \\
Diabetic + control & $8.77 \pm 5.59^{\mathrm{a}}$ \\
Diabetic + 600 GS & $-33.87 \pm 13.79^{\mathrm{b}}$ \\
Diabetic + 600 CM & $-68.26 \pm 4.01^{\mathrm{b}}$ \\
Diabetic + 600 GSCM & $-34.97 \pm 15.80^{\mathrm{b}}$ \\
Diabetic+Glibenclamide & $-38.10 \pm 10.35^{\mathrm{b}}$ \\
\hline
\end{tabular}

Values Mean \pm SEM with those bearing different superscripts under the same column significantly different $(\mathrm{P}<0.05) ; \mathrm{N}=6 ;(+)$ preceding a value means \% increase in $\mathrm{FBG} ;(-)$ preceding a value means $\%$ decrease in FBG.

Table 3: Relationship between \% Decrease in FBG of Rats and In vitro Antioxidant Capacity of Gymnema sylvestre and Combretum micranthum Leaves

\begin{tabular}{|c|c|c|c|c|c|c|c|}
\hline \multicolumn{2}{|c|}{ Pearson Correlations } & $\% \mathrm{FBG}$ & $\begin{array}{l}\text { TOT } \\
\text { FLAV }\end{array}$ & $\begin{array}{c}\text { TOT } \\
\text { PHENOL }\end{array}$ & ABTS & DPPH & NOXIDE \\
\hline \multirow{2}{*}{$\% \mathrm{FBG}$} & $\mathrm{r}$ & 1 & .343 & .375 & $.847^{* * *}$ & $.719^{*}$ & $.810^{*}$ \\
\hline & $\mathrm{p}$ & & .657 & .625 & .008 & .044 & .015 \\
\hline
\end{tabular}




\begin{tabular}{|c|c|c|c|c|c|c|c|}
\hline \multirow{2}{*}{ TOTFLAV } & $\mathrm{r}$ & .343 & 1 & $.975^{*}$ & $-.999^{* *}$ & $-.977^{*}$ & $-.984^{*}$ \\
\hline & $\mathrm{p}$ & .657 & & .025 & .001 & .023 & .016 \\
\hline \multirow{2}{*}{ TOTPHENOL } & $\mathrm{r}$ & .375 & $.975^{*}$ & 1 & $-.962^{*}$ & $-.994^{* *}$ & $-.999^{* *}$ \\
\hline & $\mathrm{p}$ & .625 & .025 & & .038 & .006 & .001 \\
\hline \multirow{2}{*}{ ABTS } & $\mathrm{r}$ & $.847^{* *}$ & $-.999^{* *}$ & $-.962^{*}$ & 1 & $.922^{* * *}$ & $.940 * *$ \\
\hline & $\mathrm{p}$ & .008 & .001 & .038 & & .001 & .001 \\
\hline \multirow{2}{*}{ DPPH } & $\mathrm{r}$ & $.719^{*}$ & $-.977^{*}$ & $-.994^{* *}$ & $.922^{* * *}$ & 1 & $.845^{* *}$ \\
\hline & $\mathrm{p}$ & .044 & .023 & .006 & .001 & & .008 \\
\hline \multirow{2}{*}{ NOXIDE } & $r$ & $.810^{*}$ & $-.984^{*}$ & $-.999^{* *}$ & $.940^{* *}$ & $.845^{* *}$ & 1 \\
\hline & $\mathrm{p}$ & .015 & .016 & .001 & .001 & .008 & \\
\hline
\end{tabular}

** Correlation is significant at the 0.01 level (2-tailed). * Correlation is significant at the 0.05 level (2-tailed). $r=$ correlation coefficient; $\mathrm{p}=$ significance level.

Table 4: Relationship between \% Decrease in FBG, In vivo Antioxidant/Peroxidation Status in Rats Administered Gymnema sylvestre and Combretum micranthum Aqueous Leaf Extracts

\begin{tabular}{|c|c|c|c|c|c|}
\hline \multicolumn{2}{|c|}{ Pearson Correlations } & $\% \mathrm{FBG}$ & MDA & ROS & CAT \\
\hline \multirow{2}{*}{$\%$ FBG } & $r$ & 1 & $.337^{*}$ & .282 & .393 \\
\hline & $\mathrm{p}$ & & .036 & .082 & .013 \\
\hline \multirow{2}{*}{ MDA } & $\mathrm{r}$ & $.337^{*}$ & 1 & $.530 * *$ & .220 \\
\hline & $\mathrm{p}$ & .036 & & .000 & .151 \\
\hline \multirow{2}{*}{ ROS } & $\mathrm{r}$ & .282 & $.530 * *$ & 1 & .221 \\
\hline & $\mathrm{p}$ & .082 & .000 & & .150 \\
\hline \multirow{2}{*}{ CAT } & $\mathrm{r}$ & $.393^{*}$ & .220 & .221 & 1 \\
\hline & $\mathrm{p}$ & .013 & .151 & .150 & \\
\hline
\end{tabular}

** Correlation is significant at the 0.01 level (2-tailed). * Correlation is significant at the 0.05 level (2-tailed). $r=$ correlation coefficient; $p=$ significance level.

\section{Discussion}

Superoxide dismutase (SOD), catalase (CAT), glutathione peroxidase (GSH-Px), and glutathione-S-transferase (GST) are endogenous antioxidant enzymes responsible for the detoxification of deleterious oxygen radicals and their activities are used to assess oxidative stress in cells. The first line of defense to the cells is provided by the existence of a mutually supportive relationship between metalloenzyme $\mathrm{SOD}$, which accelerates the dismutation of endogenous cytotoxic superoxide radicals to $\mathrm{H}_{2} \mathrm{O}_{2}$, and CAT, which converts the deleterious peroxide radicals into water and oxygen. In the present study, the activity of hepatic SOD was increased in the treated rats. The induction of this antioxidant enzyme may indicate an adaptive response 
to counter the damaging effect of oxidative stress possibly generated during metabolism. Glutathione plays a pivotal role in the scavenging of hydroxyl radical and singlet oxygen directly as well as in the detoxification of hydrogen peroxides and lipid hydro-peroxides by the activity of GSH-Px. Further, GST is involved in the biochemical conjugation of electrophilic oxidants with GSH to form water soluble compound products that are readily excreted from the system. The observed decrease in the hepatic GSH level (for GS \& CM individually) in the present study may suggest an increased demand or overutilization of GSH by the cell possibly to combat ROS generation in the rats - however, in combined form, GSCM increased GSH levels signifying better ability to combat radicals through the Phase II reaction mechanism. The deleterious chemical effects of $\mathrm{H}_{2} \mathrm{O}_{2}$ molecules can be divided into the categories of direct activity, originating from their oxidizing properties, and indirect activity in which they serve as a source for more deleterious species, such as hydroxyl radicals and hypochlorous acid. Reactive oxygen species attack cellular components containing polyunsaturated fatty acid residues to produce peroxyl radicals which undergo a cyclization reaction to form endoperoxides and eventually trans-4hydroxy-2-nonenal and MDA. The increases in the hepatic MDA levels observed in this study clearly indicate a state of stress in the tissues possibly induced by the extracts or their metabolites.

Ability of the plants to combat oxidative stress is further supported by in vitro antioxidants (radical scavenging) activities where they were found to have scavenging activities against DPPH, ABTS and Nitric Oxide with a very good FRAP - all the in vitro antioxidant parameters correlate well with the in vivo ones; which agree with the work of Touré et. al. (2011). The radical scavenging activities of the plants could be attributed to the total phenolics and total flavonoids contents (Aiyegoro \& Okoh 2010; Djeridane et. al., 2010; Prathapan et. al., 2012), compounds that are capable of donating hydrogen to a free radical in order to remove odd electron which is responsible for radical's reactivity. The scavenging activity of $\mathrm{ABTS}^{+}$radical by the plants extract was found to be appreciable; this implies that the plant extract may be useful for treating radical related pathological damage.

Nitric oxide (NO) is a reactive free radical produced by phagocytes and endothelial cells, to yield more reactive species such as peroxynitrite which can be decomposed to form $\mathrm{OH}$ radical. The level of nitric oxide was significantly reduced in this study by the crude extracts. Since NO plays a crucial role in the pathogenesis of inflammation, these plants (GS \& CM) might be useful in curbing ulcerations. Plants with antioxidant activities have been reported to possess free radical scavenging activity. Free radicals are known as major contributors to several clinical disorders such as diabetes mellitus, cancer, liver diseases, renal failure and degenerative diseases as a 
result of deficient natural antioxidant defense mechanism (Aiyegoro \& Okoh, 2010; Alexiou \& Demopoulos, 2010; Yasir et. al., 2012; Mistry and Mona, 2015).

Hyperglycaemia-induced impairments in redox balance are considered a key trigger of diabetic complications, through up-regulated generation of reactive oxygen species (ROS), together with an impaired ability of the endogenous antioxidant defense system to remove them (Huynh et. al., 2013). The current study has displayed the ability of the plants, GS and CM to have glucose lowering effect which correlates well with reduced ROS in rats and improved antioxidant parameters like CAT, GSH, GSSG, GSH-Px and MDA, hence suggesting that the plants improved ability of the endogenous antioxidant defense system could be through their hypoglycaemic activity.

\section{Conclusion}

$G$. sylvestre and $C$. micranthum leaf extracts showed reduction in ROS and MDA. Both plants also displayed radical scavenging activities against ABTS, DPPH and Nitric Oxide which is not unconnected with the high total flavonoids and total phenolic contents which might be responsible for the hypoglycaemia.

\section{Acknowledgements}

The authors wish to acknowledge funding support for the research provided by Tertiary Education Trust Fund (tetFUND) and Bayero University, Kano - Nigeria (Scholarship Award No: BUK/R/TEPIC/SB5/N05).

\section{References:}

1. Abdullahi, M. H., Anuka, J. A., Yaro, A. H., and Musa, A. (2014). Effect of Aqueous Leaf Extract of Combretum micranthum G. Don (Combretaceae) on Gastro Intestinal Smooth Muscle. Bayero Journal of Pure and Applied Sciences (BAJOPAS), 7(2), 21-25.

2. Adedara, I. A, Abolaji, A. O., Odion, B. E., Okwudi, I. J., Omoloja, A. A, \& Farombi, E. O. (2014). Impairment of hepatic and renal functions by 2,5-hexanedione is accompanied by oxidative stress in rats. Journal of Toxicology, 2014, 239240. doi:10.1155/2014/239240

3. Aiyegoro, O. A, and Okoh, A. I. (2010). Preliminary phytochemical screening and in vitro antioxidant activities of the aqueous extract of Helichrysum longifolium DC. BMC Complementary and Alternative Medicine, 10, 21. doi:10.1186/1472-6882-10-21

4. Alexiou, P. and Demopoulos, V. J. (2010). 2. Medicinal plants used for the treatment of diabetes and its long-term complications. In: 
Eugene Kokkalou (Ed.) Plants in Traditional and Modern Medicine: Chemistry and Activity, 69-175, Kerala, India Transworld Research Network.

5. Beutler, E., Duron, O., and Kelly, B.M., (1963). Improved method for the determination of blood glutathione. J. Lab. Clin. Med. 61, $882-888$.

6. Chatzigeorgiou, A., Halapas, A., Kalafatakis, K., and Kamper, E. (2009). The Use of Animal Models in the Study of Diabetes Mellitus. In Vivo (Athens, Greece), 23(2), 245-58. Retrieved from http://www.ncbi.nlm.nih.gov/pubmed/19414410

7. Chika, A., and Bello, S. O. (2010). Antihyperglycaemic activity of aqueous leaf extract of Combretum micranthum (Combretaceae) in normal and alloxan-induced diabetic rats. Journal of Ethnopharmacology, 129(1), 34-37. doi:10.1016/j.jep.2010.02.008

8. Clairborne, A. (1995) "Catalase activity," in Handbook of Methods for Oxygen Radical Research, A. R.Greewald,Ed., CRC Press, Boca Raton, Fla, USA,. pp. 237-242.

9. Djeridane, A., Yousfi, M., Brunel, J. M., \& Stocker, P. (2010). Isolation and characterization of a new steroid derivative as a powerful antioxidant from Cleome arabica in screening the in vitro antioxidant capacity of 18 Algerian medicinal plants. Food and Chemical Toxicology, 48(10), 2599-2606. doi:10.1016/j.fct.2010.06.028

10. Doughari, J. H. (2012). Phytochemicals: Extraction Methods, Basic Structures and Mode of Action as Potential Chemotherapeutic Agents, In: Dr Venketeshwer Rao (Ed.), Phytochemicals - A Global Perspective of Their Role in Nutrition and Health, InTechOpen, http://www.intechopen.com/books/phytochemicals-a-globalperspective-of-their-role-in-nutrition-and-health/phytochemicalsextraction-methods-basic-structures-and-mode-of-action-as-potentialchemotherapeutic-InTech. Pp 1-33.

11. Erel, O. (2005). A new automated colorimetric method for measuring total oxidant status. Clinical Biochemistry, 38(12), 1103-11111. doi:10.1016/j.clinbiochem.2005.08.008

12. Huynh, K., Kiriazis, H., Du, X., Love, J. E., Gray, S. P., Jandeleitdahm, K. A., and Ritchie, R. H. (2013). Targeting the upregulation of reactive oxygen species subsequent to hyperglycaemia prevents type 1 diabetic cardiomyopathy in mice. Free Radical Biology and Medicine, 60, 307-317.

13. Kang, M. H., Lee, M. S., Choi, M. K., Min, K. S., \& Shibamoto, T. (2012). Hypoglycemic activity of Gymnema sylvestre extracts on 
oxidative stress and antioxidant status in diabetic rats. $J$ Agric Food Chem, 60(10), 2517-2524. http://doi.org/10.1021/jf205086b [doi]

14. Misra, H.P. and Fridovich, I. (1972). The role of superoxide anion in the autooxidation of epinephrine and a simple assay for superoxide dismutase. Journal of Biological Chemistry 247: 3170-3175.

15. Mistry, A. M. and Mona, S. O. (2015). Advanced glycation endproducts: modifiable environmental factors profoundly mediate insulin resistance. Journal of Clinical Biochemistry and Nutrition, 57(1), 1-12. doi:10.3164/jcbn.15

16. Miyazawa T. (1989). Determination of phospholipid hydroperoxides in human blood plasma by a chemiluminescence-HPLC assay. Free Radic Biol Med; 7: 209-217.

17. Naskar, S., Islam, A., Mazumder, U. K., Saha, P., Haldar, P. K., \& Gupta, M. (2010). In Vitro and In Vivo Antioxidant Potential of Hydromethanolic Extract of Phoenix dactylifera Fruits. Journal of Scientific Research, 2(1). doi:10.3329/jsr.v2i1.2643

18. Niehaus, W.G. and Samuelson,B. (1968). Formation of malondialdehyde from phospholipids arachidonate during microsomal lipid peroxidation. Eur.J.Biochem.6, 126-130.

19. OECD. (2006). Repeated Dose 28-day oral Toxicity Study in Rodents; Updated with Parameters for endocrine effects. http://www.oecd.org/dataoecd. Retrieved June, 2016.

20. Prathapan, A., Krishna, M. S., Nisha, V. M., Sundaresan, A., \& Raghu, K. G. (2012). Polyphenol rich fruit pulp of Aegle marmelos (L.) Correa exhibits nutraceutical properties to down regulate diabetic complications - An in vitro study. Food Research International, 48(2), 690-695. doi:10.1016/j.foodres.2012.06.008

21. Puertas, M. C., Martínez-Martos, J. M., Cobo, M. P., Carrera, M. P., Mayas, M. D., \& Ramírez-Expósito, M. J. (2012). Plasma oxidative stress parameters in men and women with early stage Alzheimer type dementia. Experimental Gerontology, 47(8), 625-630. doi:10.1016/j.exger.2012.05.019

22. Rotruck,J.T.,Pope,A.L.,Ganther,H.E., $\quad$ and Swason,A.B.,(1973).Selenium:biochemical role as a component of glutathione peroxidase.Science 179, 588-590.

23. Shirwaikar, A., Rajendran, K. and Barik, R. (2006). Effect of aqueous bark extract of Garuga pinnata Roxb in streptozotocin-nicotinamide induced type-II diabetes mellitus. J. Ethnopharmacol., 107: 285-290.

24. Timbrell, J. (1996). Biochemical toxicology. Critical reviews in biochemistry and molecular biology (Vol. 31), Pp 224 - 225. 
25. Tiwari, P., Mishra, B. N., and Sangwan, N. S. (2014). Phytochemical and pharmacological properties of Gymnema sylvestre: An important medicinal plant. BioMed Research International, 2014(ID 830285).

26. Touré, A., Xu, X., Michel, T., \& Bangoura, M. (2011). In vitro antioxidant and radical scavenging of Guinean kinkeliba leaf (Combretum micranthum G. Don) extracts. Natural Product Research, 25(11), 1025-36. doi:10.1080/14786419.2010.482048

27. Upendra Rao, M., Sreenivasulu, M., Chengaiah, B., Jaganmohan Reddy, K., \& Madhusudhana Chetty, C. (2010). Herbal medicines for diabetes mellitus: A review. International Journal of PharmTech Research, 2(3), 1883-1892.

28. Yasir, M., Shrivastava, R., Jain, P., \& Das, D. (2012). Hypoglycemic and Antihyperglycemic Effects of Different Extracts and Combinations of Withania coagulans Dunal and Acacia arabica Lamk in Normal and Alloxan Induced Diabetic Rats. Pharmacognosy Communications, 2(2), 61-66. doi:10.5530/pc.2012.2.9

29. Yeni, E., Gulum, M., Selek, S., Erel, O., Unal, D., Verit, A, and Savas, M. (2005). Comparison of oxidative/antioxidative status of penile corpus cavernosum blood and peripheral venous blood. International Journal of Impotence Research, 17(1), 19-22. doi:10.1038/sj.ijir.3901262 